\title{
AIKUINEN OPPII ERI TAVALLA
}

\author{
OECD \& U.S. Departe- \\ ment of Education.
} (1999). How adults

learn. Washington:

U.S. DEPARTMENT OF EDUCATION.

\section{Elinikäisen oppimisen} järjestäminen edellyttäisi ihmisen koko elämänkaaren mittaista tarkastelua. Silti erityisaseman saa työikäisen väestön oppimismahdollisuuksien varmistaminen. Aikuisväestöä varten ei yleensä myöskään ole samanlaisia lakiin perustuvia oppimismahdollisuuksia, joita on peruskoulutukseen suuntautuvassa koulutusjärjestelmässä. Yksi tapa määrittää oppiminen on kertoa, että se on entistä parempaa ja kehittyneempää osallistumista interaktiivisiin järjestelmiin. Tämä James Greenon filosofia lähtee myös siitä, että kaikki työssä olevat tietävät, millaisilla taidoilla on merkitystä ja kykenevät osallistumaan sosiaalisiin järjestelmiin.

\section{Greenon ajattelu oli} OECD:n aikuisten oppimista käsitelleen konferenssin keskustelun pohjana. Teemoja oli kolme: 1) heikon funktionaalisen lukutaidon omaavien siirtolaisten, 2) perustaidoissa puutteita omaavien aikuisten ja 3) vanhimman ikäryhmän koulutuksen järjestäminen. Siirtolaisten oppimisessa korostetaan mm. työn järjestämistä monikulttuurisissa ryhmissä, joissa aina olisi mukana myös maan kieltä syntyperäisesti puhuvia. Vanhimman väestönosan niin kuin mui- denkin aikuisten opiskelu näyttää useissa kulttuureissa kaatuvan siihen, että aikuisten opetus yritetään järjestää yhdessä nuorten kanssa. Koulutus on myös riittämättömästi kytketty aikaisemmin opittuun. Lisävaikeuksia aiheutuu siitä, että kyytiä opiskelupaikalle ei ole järjestetty ja että kurssimaksut ovat korkeita.

\section{Konferenssin raportista} selviää, että koulumainen opettamis-oppimis -filosofia ei tuota parasta tulosta aikuisten oppimismaailmassa. Koulutuksessa pitäisi lopettaa aikuisten kohtelu suurina lapsina. Parhaat toimintatavat opettamiseen ja oppimiseen on kehitetty lähiyhteisöissä ja työpaikoilla, joissa aikuiskoulutus on kyetty muuttamaan aikuisten oppimiseksi. Aikuisten oppimisen edistämiseksi on tuotettu runsaasti innovaatioita, mutta tällä hetkellä ei ole mitään systemaattista tapaa laittaa "hyvät käytännöt" paremmuusjärjestykseen. Ei ole myöskään mitään selkeää näkemystä, miten oppimisyhteiskunnan ideologia toteutettaisiin käytännössä. Vanhemman ikäluokan kannalta hyödyllisiin ohjelmiin liittyy usein oppimisen itseohjautuvuus.

\section{Politiikkasuosituksissa korostetaan, kuinka keskeistä on tuottaa tutkimustietoa ai- kuisten oppimisen mitattavis- ta hyödyistä ja markkinoida tätä tietoa aikuisväestölle ja päättäjille. Pitää varmistaa, että opiskeluun on olemassa te- hokkaat kiihottimet ja taata opiskelumahdollisuudet.}

Opiskeluvalinnat on voitava tehdä tietoisesti hyvän informaation pohjalta. Koulutuksen järjestämisessä tarvitaan tietoa siitä, miten aikuiset oppivat. Tämän pitäisi ohjata opetussuunnitelman ja opetusmetodien valinnassa. Käytännön aikuiskouluttajien ja tutkijoiden pitää lisätä yhteistyötä sen selvittämiseksi, miten "parhaiksi käytännöiksi" nostetuista ohjelmista voitaisiin kokemuksen perusteella saada suurin hyöty.

Raportti ei sisällä mitään perin uutta tai yllättävää. Siinä on kuitenkin joukko korkeatasoisia artikkeleita, joihin koulutussuunnittelijoiden ja aikuiskoulutuksen tutkijoiden on hyödyllistä perehtyä.

\section{Reijo Laukkanen}

\section{Uutta kirjallisuutta}

Reijo Laukkanen ja Matti Kyrö (toim.) Oppia OECD:n analyyseista. Opetushallitus 2000. 153 sivua

Pia-Lena Leskinen (1999) "Yrittäjällä on koko elämä kiinni yrityksessä". Opiskelijoiden yrittäjyyskäsitykset ja niiden muutokset yritysprojektin aikana. Acta Wasaensia. 353 sivua

Oppisopimuskoulutus. Tavoitteet, strategiat, rahoitus, tulokset. Valtiontalouden tarkastusvirasto, tarkastuskertomus 2/ 2000 .

Juha Varila ja Taija Viholainen (2000). Työnilo tutkimuksen kohteeksi. Joensuun yliopisto. Kasvatustieteellisen tiedekunnan tutkimuksia 79 . 